\title{
Dose calculation in Abdominal-Pelvic CT examinations from two hospitals in the Lisbon area
}

\section{Cálculo de Doses em exames de TC Abdómen-Pélvico em dois hospitais da região de Lisboa}

\author{
Tânia Umbelino ${ }^{1}$, Tatiana Silva ${ }^{1}$, Frederico Teixeira ${ }^{1}$, Luís Mendes $^{1}$, Piedade Falcão $^{2}$, \\ Paulo Pereira $^{1} \&$ Nuno Matela ${ }^{1,3}$ \\ 'ERISA - Escola Superior de Saúde Ribeiro Sanches, Direcção de Radiologia, \\ Rua do Telhal aos Olivais, n8 - 8a , 1900-693 Lisboa \\ ${ }^{2}$ Centro Hospitalar Lisboa Central, Hospital São José \\ ${ }^{3}$ Instituto de Biofísica e Engenharia Biomédica, Faculdade de Ciências, Universidade de Lisboa \\ Email: taniamafalda@hotmail.com
}

\begin{abstract}
This work aims to evaluate whether the dose values received by patients submitted to Abdominal-pelvic Computed Tomography (CT) in two hospitals in the Lisbon area do agree with the Diagnostic Reference Levels. The dosimetric units of examinations performed with modulated and continuous current in both hospitals were also compared.

The study consisted in collecting data from 200 abdominal - pelvic CT's, obtained in two hospitals (100 per hospital) . In Hospital A, the mean DLP was $562.34 \mathrm{mGy} . \mathrm{cm}$ and the average values CTDIvol was $12.06 \mathrm{mGy}$. In Hospital B, the mean DLP and CTDIvol was $767.14 \mathrm{mGy} . \mathrm{cm}$ and $15.02 \mathrm{mGy}$, respectively.

We have concluded that, from this sample, none of the dosimetric units values exceeded the Diagnostic Reference Levels values. It was also noted that tests performed in B involved higher doses of patient exposure to ionizing radiation.
\end{abstract}

Keywords: Abdomen-pelvic CT; Dosimetric units; Diagnostic Reference Levels; modulated current; continuous current;

\begin{abstract}
Resumo
Este trabalho tem como objectivo avaliar se os valores de dose recebida pelos doentes que realizam exames de Tomografia Computorizada (TC) Abdómen-pélvicos em dois hospitais da grande Lisboa estão de acordo com os Níveis de Referência de Diagnóstico Europeus (NRD). Foram comparadas também as unidades dosimétricas de exames realizados com corrente modelada e de exames realizados com corrente contínua em ambos os hospitais. O estudo consistiu na recolha de dados de 200 exames de TC Abdómen-pélvicos, 100 em cada hospital. No Hospital A, a média dos valores de DLP foi 562,34 mGy.cm e a média dos valores de CTDIvol foi 12,06 mGy. No Hospital B, a média dos valores DLP e CTDIvol foi 767,14 mGy.cm e 15,02 mGy, respectivamente.

No total da nossa amostra, concluiu-se que em nenhum exame os valores de unidades dosimétricas ultrapassam os valores dos NRD. Verificou-se também que os exames realizados no Hospital B implicam em média uma maior dose de radiação ionizante para o doente.
\end{abstract}

Palavras-chave: TC Abdómen-pélvico; Unidades dosimétricas; Níveis de Referência de Diagnóstico; corrente modelada; corrente contínua 


\section{Introduction}

The Computed Tomography (CT) represents the natural evolution of radiological imaging with X-rays. Since it was introduced into clinical practice, back in the 70 's, major improvements in image quality were achieved, overcoming some limitations presented by the so-called "conventional" radiology ${ }^{[1,2]}$. Given the advantages of this diagnostic technique, its usefulness in clinical practice has been growing steadily around the world, since the first examination, in 1972, registering a $10 \%$ growth per year in the number of CT exams, in diagnostic and therapeutic ${ }^{[3]}$. However, this also resulted in a substantial rise in radiation exposure to patients during medical diagnosis, where CT is responsible for about $40 \%$ of medical diagnostic radiation dose ${ }^{[3]}$. Therefore, the patient exposure dose resulting from medical CT scans, is an important public health issue, concerning experts in different countries (in Europe and the United States of America) ${ }^{[2,4]}$. As a consequence, it became necessary to establish dose reference levels which, without interfering with the quality of diagnosis, could favor dose optimization.

The concept of X-ray examinations "Diagnostic Reference Levels" (DRL) was introduced in the UK in $19900^{[4]}$. In 1997, the DRL definition was established as mandatory for medical radiology examinations or diagnostic within the European Union member states, by the 97/43/EURATOM Directive and the European Atomic Energy Community (EURATOM). This directive settles basic safety standards for the health protection of workers and the general population, against the risks arising from ionizing radiation ${ }^{[6]}$. In August 2002, this Directive was transposed into the Portuguese legislative framework through the Dec-Lei $180 / 2002$. According to this the DRL is defined as "dose levels in medical practice radiodiagnostic or, in the case of radio-pharmaceuticals, levels of activity tests of typical groups sized patients or models for the standard types of equipment broadly defined. These levels should not be exceeded for standard procedures when applying good practice regarding diagnostic and technical performance ${ }^{\text {[[]]. }}$

\section{Introdução}

A Tomografia Computorizada (TC) representa a evolução lógica e natural da imagem radiográfica convencional utilizando radiação X. Assim, desde que foi introduzida na prática clínica na década de 70 , proporcionou uma melhoria na qualidade de imagem, contornando algumas limitações apresentadas pela radiologia dita "convencional" "[1,2].

Perante as vantagens oferecidas por esta técnica de diagnóstico, a sua utilidade na prática clínica foi crescendo progressivamente, em todo o mundo, desde a realização do primeiro exame, em 1972, verificando-se um crescimento de cerca de $10 \%$ ao ano no número de exames de TC, quer diagnósticos quer terapêuticos ${ }^{[3]}$. No entanto, a sua utilização crescente trouxe como consequência o aumento substancial das doses de radiação por exposições médicas de diagnóstico, sendo a TC responsabilizada por cerca de $40 \%$ da radiação médica diagnóstica ${ }^{[3]}$. Assim, a dose para o paciente resultante dos exames de TC para fins médicos, constituem uma questão importante de Saúde Pública que inquieta especialistas em diversos países (europeus e nos Estados Unidos da América) ${ }^{[2,4]}$.

Em consequência surgiu a necessidade de estabelecer níveis de dose de referência que, sem interferir com a qualidade do diagnóstico, pudessem apontar para uma optimização das doses.

O conceito de "Níveis de Referência de Diagnóstico" (NRD) para exames de raios $\mathrm{X}$ foi introduzido no Reino Unido, em $1990{ }^{[5]}$. Em 1997, a obrigatoriedade de definição dos NRD em exames médicos de radiodiagnóstico foi instituída nos Estados-membros da União Europeia através da Comunidade Europeia de Energia Atómica (EURATOM) pela Directiva 97/43/EURATOM. Esta prevê o estabelecimento de normas básicas de segurança relativas à protecção da saúde dos trabalhadores e da população em geral, contra os perigos resultantes das radiações ionizantes ${ }^{[6]}$. Em Agosto de 2002, ocorreu a transposição desta Directiva para o quadro legislativo português através do Decreto-Lei no 180/2002. Segundo este DecretoLei, os NRD definem-se como "níveis de doses na prática médica de radiodiagnóstico ou, no caso de produtos radiofármacos, níveis de actividade para exames típicos em grupos de pacientes de tamanho médio ou em modelos-padrão para tipos de equipamento de definição alargada. Estes níveis não devem ser ultrapassados nos procedimentos habituais quando são aplicadas as boas práticas correntes relativas ao diagnóstico e à qualidade técnica" ${ }^{[7]}$. 
Table 1 - Dose reference levels in CT, adapted from ${ }^{[8]}$

Tabela 1 - Níveis de referência de dose em exames de TC, adaptado de ${ }^{[8]}$

\begin{tabular}{cccc}
\hline Examination & CTDIw $(\mathbf{m G y})$ & DLP $(\mathbf{m G y} . \mathbf{c m})$ & Phantom \\
Exame & 60 & 1050 & Hantasma \\
\hline Routine Head & 35 & 360 & Head \\
Face and sinuses & 70 & 460 & Body \\
Vertebral Trauma & 30 & 650 & Body \\
Routine Chest & 35 & 280 & Body \\
Lung HRCT & 35 & 780 & Body \\
Routine Abdomen & 35 & 900 & Body \\
Liver and Spleen & 35 & 570 & Body \\
Routine pelvis & 25 & 520 & Body \\
Osseus pelvis & & & \\
\hline
\end{tabular}

CTDIw (Computerised Tomography Dose Index)

DLP (Dose-Length Product)

In $\mathrm{CT}$, the DRL proposals have been based on measurements from several European countries (Table1) ${ }^{[8]}$. In CT, the DRL are usually calculated from the CTDI (Computerised Tomography Dose Index) quantity which is measured in the isocenter of the scanner with phantom dimensions and attenuation coefficients similar to the human body ${ }^{[9]}$. This quantity depends on the exposure parameters such as tube voltage, tube current and exposure time. The CTDI is defined as the value of the total dose received by the patient in each slice and is expressed in Gray (Gy) units. This definition has some variations, such as $\mathrm{CTDI}_{\mathrm{w}}$ or $\mathrm{CTDI}_{\mathrm{vol}}$. The CTDIw allows the calculation of a weighted dose in the center and the periphery of the scanner, and is expressed by the following equation:

$$
\mathrm{CTDI}_{\mathrm{w}}=1 / 3 \mathrm{CTDI}_{\text {center }+2 / 3} \mathrm{CTDI}_{\text {periphery }}
$$

It may be also calculated by the equation 3 equivalent, knowing that the pitch represents the ratio of the table progress and thickness.

$$
\mathrm{CTDI}_{\mathrm{w}}=\mathrm{CTDI}_{\mathrm{vol}} \mathrm{x} \text { pitch }
$$

The CTDIvol considers space or overlap between the sections and is expressed by the following equation:

$$
\mathrm{CTSI}_{\mathrm{vol}}=\mathrm{CTDI} \mathrm{w} / \text { pitch }
$$

In turn, the entire dose of a CT scan may be assessed by DLP(Dose-Length Product $)$ as follows ${ }^{[9]}$ :

$$
\begin{gathered}
\mathrm{DLP}=\mathrm{CTDI} \text { w. No cuts. slice thickness } \\
\text { pitch }
\end{gathered}
$$

Em TC, os níveis de referência de diagnóstico têm sido propostos com base em medições feitas em vários países europeus - (Tabela 1) ${ }^{[8]}$. Em TC, os níveis de referência de diagnóstico são, normalmente, calculados com base na grandeza CTDI (Computerised Tomography Dose Index) que é medida no isocentro do scanner com fantomas com dimensões e coeficientes de atenuação semelhantes aos do corpo humano ${ }^{[9]}$. Esta grandeza depende dos parâmetros de exposição como a voltagem, corrente do tubo e tempo de exposição. O CTDI define-se como o valor da dose total recebida pelo paciente em cada corte e expressa-se pela unidade Gray (Gy). Esta grandeza possui as variações CTDI $_{\text {w }}$ e CTDI ${ }_{\text {vol }}$. O CTDI w $_{\text {p }}$ permite calcular a dose ponderada no centro e na periferia do scanner, e traduz-se pela seguinte equação:

$$
\mathrm{CTDI}_{\mathrm{w}}=1 / 3 \mathrm{CTDI}_{\text {centro }}+2 / 3 \mathrm{CTDI}_{\text {periferia }}
$$

Pode também ser calculado pea seguinte equação, equivalente à equação 3 , sabendo que o pitch representa a razão entre o andamento da mesa e a espessura de corte.

$$
\mathrm{CTDI}_{\mathrm{w}}=\mathrm{CTDI}_{\mathrm{vol}} \mathrm{x} \text { pitch }
$$

$\mathrm{O} \mathrm{CTDI}_{\mathrm{vol}}$ considera o espaço ou a sobreposição entre os cortes e traduz-se pela seguinte equação:

$$
\mathrm{CTDI}_{\mathrm{vol}}=\mathrm{CTDI}_{\mathrm{w}} / \text { pitch }
$$

Por sua vez, a totalidade da dose de um exame de TC pode ser avaliada através do DLP (Dose-Length Product) que se traduz pela equação seguinte ${ }^{[9]}$ :

$$
\mathrm{DLP}=\underline{\mathrm{CTDI}} \underline{w}_{\underline{w}} \frac{\mathrm{n}^{\mathrm{o}} \text { cortes . espessura de corte }}{\text { pitch }}
$$

Tendo como objectivo relacionar a dose efectiva de 
In order to relate the effective dose of a diagnostic examination with the time required to obtain the same dose from natural radiation, it is possible to calculate the magnitude of BERT (Background Radiation Equivalent Time.) This is an ionizing radiation unit used in health radiology as a standard for the definition of exposure limits ${ }^{[11]}$. This dosimetric unit is defined by the following formula, where $\mathrm{E}$ is the effective dose:

$$
\mathrm{BERT}=\mathrm{E} / 2.4 \text { [years] }
$$

One factor greatly affecting the radiation dose in $\mathrm{CT}$ is the tube current. This might be modulated or continuously programmed by the most modern CT equipment ${ }^{[10]}$. With the continuous tube, current is constantly maintained throughout the examination, regardless of the characteristics of the anatomical structure including its thickness. In the modulated tube current, the tube current depends on the characteristics of the anatomical structure examined, increasing or decreasing the mAs value, which includes the object thickness.

Techniques that use modeled tube current allow a constant image quality in all images of a particular examination, because the level of exposure will vary with the attenuation of the beam, because the modeling of the tube current is based on differences in the anatomical regions, with the purpose of maintaining constant the noise at all the images with an optimal dose ${ }^{[10]}$.

The main limitation of the use of these techniques is the lack of uniformity among the techniques developed by different suppliers. Thus, it is necessary that the various companies, radiologists, medical physicists and radiographers reach a consensus in order to minimize confusion and ensure the appropriate use of the technique ${ }^{[10]}$.

The present study was to assess if the values of dose received by patients who perform Computed Tomography (CT) abdomen-pelvic examinations in two hospitals of Lisbon are in accordance with the Diagnostic Reference Levels of European (NRD).

\section{Material and Methods}

The present study used a specific software provided by Escola Superior de Saúde Ribeiro Sanches - ERISA, to calculate CT doses. This software, called "CT Dosimetry" from ImPACT-CT, simulates the radiation received by a phantom, in a selected anatomical area. After the introduction of the technical parameters (voltage, milliamperage, pitch and collimation) of certain examinations and based on Monte Carlo calculations, values of CTDIvol, DLP and Effective Dose in $\mathrm{mGy}$, and mGy.cm mSv, are obtained (Figure 1). exames de diagnóstico com o tempo necessário para obter a mesma dose de radiação natural, calculou-se a grandeza do BERT (Background Equivalent Radiation Time). Esta é uma unidade de medida de dose de radiação ionizante, utilizada nas áreas de saúde radiológica como padrão para a definição de limites de exposição ${ }^{[11]}$. Esta unidade dosimétrica traduz-se pela seguinte fórmula, sendo o $\mathrm{E}$, a dose efectiva:

$$
\mathrm{BERT}=\mathrm{E} / 2,4[\mathrm{anos}]
$$

Um dos factores que afecta grandemente a dose de radiação em TC é a corrente do tubo. Esta pode ser programada de forma modelada ou contínua pelos equipamentos de TC utilizados nos dias de hoje. ${ }^{[10]}$. A corrente do tubo contínua, caracteriza-se por se manter constante durante todo o exame independentemente das características da estrutura anatómica em estudo como a espessura, por exemplo. Já a corrente do tubo modelada caracteriza-se por adequar a corrente do tubo consoante as características da estrutura anatómica em estudo, aumentando ou diminuindo o valor de mAs consoante a espessura do objecto.

As técnicas de utilização de corrente modelada permitem uma qualidade de imagem constante em todas as imagens de determinado exame, pois o nível de exposição será variável com a atenuação do feixe, isto porque se baseia nas diferenças das regiões anatómicas para modular a corrente do tubo com o propósito de manter o ruído constante em todas as imagens com optimização da dose ${ }^{[10]}$.

A limitação principal das técnicas de utilização de corrente modelada é a falta de uniformidade entre as técnicas desenvolvidos por diferentes fornecedores. Assim, seria necessário que as diversas empresas, os médicos radiologistas, os físicos médicos e os técnicos de radiologia chegassem a um consenso, a fim de minimizar a confusão e garantir o uso adequado da técnica ${ }^{[10]}$.

$\mathrm{O}$ presente trabalho teve como objectivo avaliar se os valores de dose recebida pelos doentes que realizam exames de Tomografia Computorizada (TC) Abdómenpélvicos em dois hospitais da grande Lisboa estão de acordo com os Níveis de Referência de Diagnóstico Europeus (NRD).

\section{Material e Métodos}

Neste estudo foi necessário utilizar um programa de doses em TC fornecido pela Escola Superior de Saúde Ribeiro Sanches - ERISA. Este programa designado por " $\underline{C T}$ Dosimetry" da ImPACT-CT, simula a radiação recebida por um fantoma, na área anatómica seleccionada. Após a introdução dos parâmetros técnicos (voltagem, miliamperagem, pitch e colimação) de determinados exames e com base nos cálculos de Monte Carlo conseguimos obter os valores de CTDI ${ }_{\text {vol }}$, DLP e Dose Efectiva, em mGy, mGy.cm e mSv, respectivamente (Figura 1). 


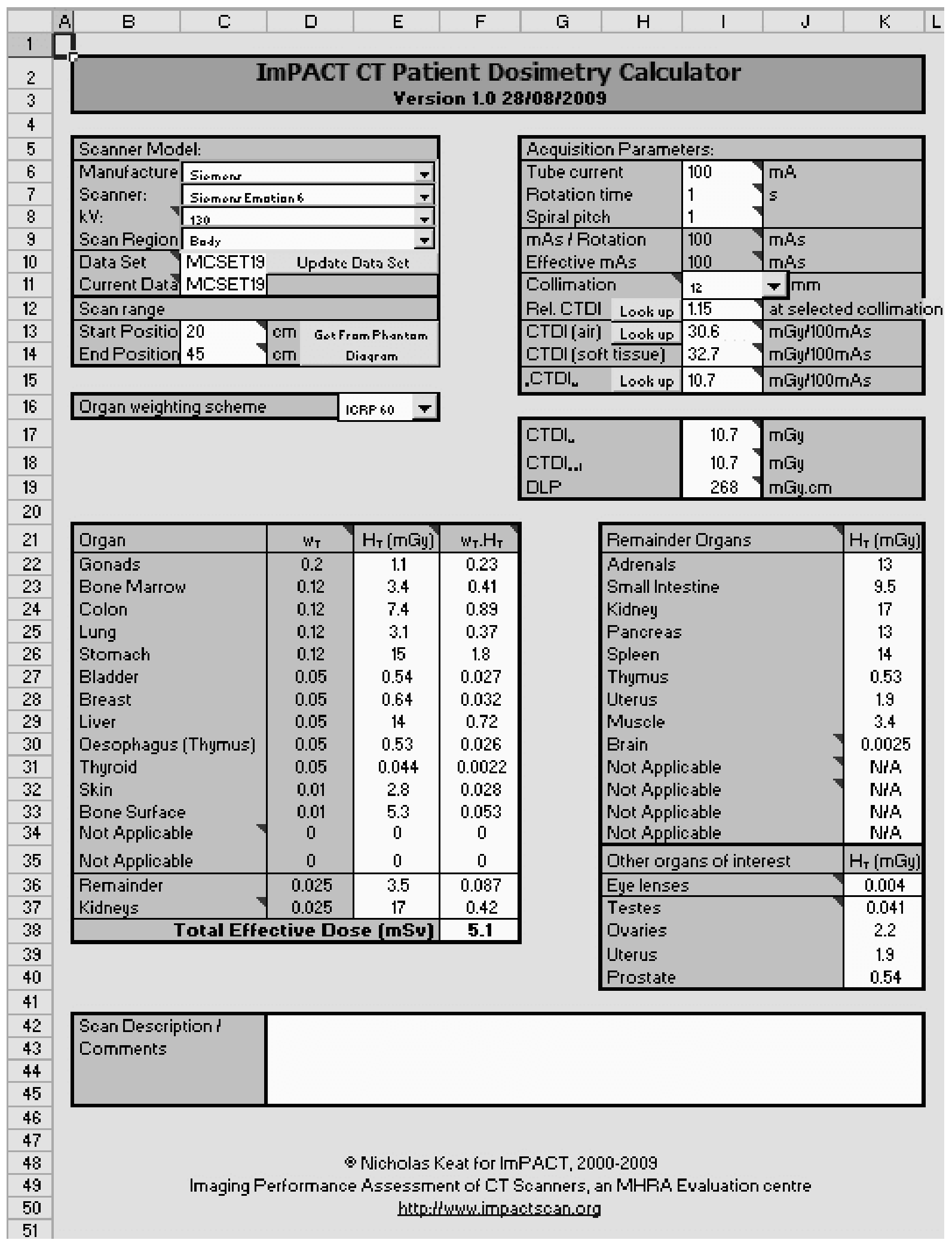

Figure 1 - Representative image of the computer program CT dosimetry adapted from ${ }^{[12]}$

Figura 1 - Imagem representativa do programa informático CT DOSIMETRY adaptado de ${ }^{[12]}$ 
Besides allowing us to calculate the effective dose for each examination (not provided by the equipment), this software also enables us to compare DLP and CTDI values provided by the data collecting equipment with those values obtained with the program ${ }^{[12 .]}$

This study was descriptive, correlational and transversal and was carried out in two major hospitals in Lisbon, which we have coded as Hospital A and Hospital B. At Hospital A, data was collected from a multislice CT equipment with 64 detectors channels from GE Medical Systems, model Light Speed. At Hospital B, the data was collected in a Philips CT equipment with the model Brilliance with 64 detectors channels.

Data collection resulted from tests held in March, April and May of 2011. These tests were conducted independently of the objectives in our study, with the adequate clinical justification. In each hospital a 100 examination sample of abdominal-pelvic CT 's was obtained from adult patients. In the Hospital A data was collected from 30 examinations with continuous tube current and 70 examinations with modulated tube current. In the Hospital B, data was collected from 83 studies with continuous tube current and from 17 studies with modulated tube current.

Number of slices, Pitch, tube current, Voltage, Collimation, DLP, and CTDIvol were registered for each examination. Data was collected in volumetric acquisitions.

At Hospital A, examinations (100) were based on the following protocol:

$120 \mathrm{kVp}$, pitch $=0.938,0.125 \mathrm{~mm}$ in slice thickness, an average of $344.40 \pm 51.79$ slices and a milliamperage average of $192.81 \pm 66.90$ mAs.

At Hospital B, examinations (100) were based on the following protocol:

The kilovoltage used was $120 \mathrm{kVp}$ values in 96 of the collected examinations, $130 \mathrm{kVp}$ in one examination and $140 \mathrm{Kvp}$ in 3 examinations; the pitch values of 1.015 were collected in 10 examinations and 1.078 on the other 90 ; a thickness of $0.1 \mathrm{~mm}$ per slice was used in 8 examinations, $0.15 \mathrm{~mm}$ in 41 examinations, $0.25 \mathrm{~mm}$ in one examination and $0.3 \mathrm{~mm}$ in the other 50, with an average of $229.3 \pm 95.09$ slices and a average milliamperage of $253.08 \pm 69.92 \mathrm{mAs}$.

Descriptive statistical analysis with calculation of central tendency and dispersion measures for the different variables was also performed through SPSS (v 17), using t-student tests on the computer software SPSS.
Além de permitir a quantificação da dose efectiva em cada exame (a qual não é fornecida pelo equipamento), este programa permitiu-nos comparar os valores de $\mathrm{CTDI}_{\mathrm{vol}}$ e DLP fornecidos pelos equipamentos onde foram recolhidos os dados, com os valores obtidos pelo programa $^{[12]}$.

Este estudo foi descritivo, correlacional e transversal, realizando-se em dois grandes Hospitais de Lisboa, os quais designamos por Hospital A e Hospital B. No Hospital A, foram recolhidos dados de um equipamento TC multicorte de 64 canais de detectores da GE Medical Systems do modelo Light Speed. No Hospital $\mathrm{B}$, os dados foram recolhidos de um equipamento de TC da Philips com o modelo Brilliance de 64 canais de detectores.

A recolha de dados foi efectuada em exames realizados nos meses de Março, Abril e Maio do presente ano. Estes exames foram realizados independentemente dos objectivos no nosso estudo e com a devida justificação clínica. Recolheram-se, então, em cada um dos hospitais uma amostra de 100 exames de TC abdómenpelvicos simples em doentes adultos.

No Hospital A foram recolhidos dados de 30 exames realizados com corrente do tubo contínua e dados de 70 exames realizados com corrente do tubo modelada. Por sua vez, no Hospital B, recolheram-se dados de 83 exames com corrente do tubo contínua e dados de 17 exames com corrente do tubo modelada.

Para a realização deste estudo, recolheram-se de cada exame os seguintes dados: número de cortes; Pitch; Corrente do tubo; Voltagem; Colimação; DLP; CTDI ${ }_{\text {vol }}$. Estes dados foram recolhidos em aquisições volumétricas.

No Hospital A, os 100 dados de exames recolhidos basearam-se no seguinte protocolo:

$120 \mathrm{Kvp}$; 0,938 de pitch; 0,125 mm de espessura de corte; uma média de cortes de $344,40 \pm 51,79$ e uma miliamperagem média de $192,81 \mathrm{mAs} \pm 66,90 \mathrm{mAs}$.

No Hospital B, os 100 dados de exames recolhidos basearam-se nos seguintes protocolos:

A kilovoltagem utilizada tomou os valores de $120 \mathrm{Kvp}$ em 96 dos exames recolhidos, $130 \mathrm{Kvp}$ em 1 exame recolhido e $140 \mathrm{Kvp}$ em 3 dos exames recolhidos; os valores de pitch foram de 1,015 em 10 dos exames recolhidos e 1,078 em 90 dos exames recolhidos; as espessuras de corte foram de $0,1 \mathrm{~mm}$ em 8 dos exames recolhidos; $0,15 \mathrm{~mm}$ em 41 dos exames recolhidos; $0,25 \mathrm{~mm}$ em 1 exame recolhido; $0,3 \mathrm{~mm}$ em 50 dos exames recolhidos; com uma média de cortes de 229,3 $\pm 95,09$ e uma miliamperagem média de $253,08 \pm 69,92$ mAs.

Foi realizada, com o SPSS (v 17) uma análise estatística descritiva com cálculo de medidas de tendência central e medidas de dispersão para as diferentes variáveis com o apoio dos testes estatísticos t-student. 


\section{Results}

By analyzing the influence of protocols variables we have realized that in Hospital A, all quantities are kept constant, except for milliamperage values and for this reason only these values were discussed. At Hospital B there are some differences in the protocols variables such as kilovoltage, pitch, slice thickness and milliamperage.

Regarding kilovoltage values, the same value of $\mathrm{kVp}$ is used in $96 \%$ of examinations. Thus, there is a very small variation in the entire sample, not sufficient to influence obtained results.

Regarding pitch values, examinations with pitch equal to 1.015 presented an average DLP of $477.22 \pm 263.55$ mGy.cm and an average CTDIvol of $9.33 \pm 4.44 \mathrm{mGy}$. Examinations that were performed with a 1.078 pitch presented an average DLP of $802.97 \pm 208.39 \mathrm{mGy} . \mathrm{cm}$ and an average CTDIvol of $15.42 \pm 3.57 \mathrm{mGy}$.

As for the slice thickness, examinations performed with a $0.3 \mathrm{~mm}$ thickness have a mean average DLP of $732.70 \pm 243.03 \mathrm{mGy} . \mathrm{cm}$ and an average CTDIvol of $14.61 \pm 4.24 \mathrm{mGy}$. In the examination with slices with a $0.25 \mathrm{~mm}$ thickness a DLP equal to $1010.5 \mathrm{mGy} . \mathrm{cm}$ and CTDIvol equal to $19,36 \mathrm{mGy}$ was obtained. Examinations performed with slices with a $0.15 \mathrm{~mm}$ thickness have an average DLP of $796.82 \pm 24870$ $\mathrm{mGy} . \mathrm{cm}$ and an average CTDIvol of $15.26 \pm 4.46 \mathrm{mGy}$. Finally, examinations performed with a $0.1 \mathrm{~mm}$ thickness have a mean DLP of $799.82 \pm 0.72$ mGy.cm and a mean CTDIvol of $15.81 \pm 0.72$ mGy. As expected, results show dosimetric units are greater for smaller slice thickness, ignoring those values from the single test performed with a $0.25 \mathrm{~mm}$ thickness which barely correspond to $1 \%$ of the Hospital B sample (Table 2).

\section{Resultados}

Ao analisarmos a influência das variáveis dos protocolos utilizados neste estudo verificámos que no Hospital A, estas assumem sempre os mesmos valores, à excepção dos valores de miliamperagem e, por esta razão só estes valores foram discutidos. No Hospital B existem algumas diferenças nas variáveis dos protocolos como a kilovoltagem, o pitch, a espessura de corte e a miliamperagem.

Quanto aos valores de kilovoltagem, em 96\% dos casos são utilizados os mesmos valores de Kvp, sendo que se verifica uma dispersão muito pequena e sem influência nos resultados obtidos.

Quanto aos valores de pitch, os exames realizados com 1,015 têm uma média de DLP de 477,22 $\pm 263,55$ mGy.cm e uma média de CTDI ${ }_{\text {vol }}$ de $9,33 \pm 4,44$ mGy e os exames realizados com 1,078 têm uma média de DLP de $802,97 \pm 208,39$ mGy.cm e uma média de CTDI $_{\mathrm{vol}} 15,42$ $\pm 3,57 \mathrm{mGy}$.

Quanto à espessura de corte, os exames realizados com $0,3 \mathrm{~mm}$ de espessura têm uma média de DLP de 732,70 \pm 243,03 mGy.cm e uma média de CTDI ${ }_{\mathrm{vol}}$ de 14,61 \pm 4,24 $\mathrm{mGy}$, no exame realizado com $0,25 \mathrm{~mm}$ de espessura obteve-se um DLP de 1010,5 mGy.cm e um CTDI vol $_{\text {de }}$ 19,36 mGy, os exames realizados com $0,15 \mathrm{~mm}$ de espessura têm uma média de DLP de 796,82 $\pm 248,70$ mGy.cm e uma média de CTDI ${ }_{\text {vol }}$ de 15,26 $\pm 4,46$ mGy e os exames realizados com $0,1 \mathrm{~mm}$ de espessura têm uma média de DLP de 799,82 \pm 0,72 mGy.cm e uma média de $\mathrm{CTDI}_{\text {vol }}$ de 15,81 $\pm 0,72 \mathrm{mGy}$. Verifica-se então tal como era previsto que quanto menor a espessura de corte, maior serão os valores das unidades dosimétricas, ignorando os valores do único exame que foi realizado com $0,25 \mathrm{~mm}$ de espessura pois este corresponde apenas $1 \%$ da amostra do Hospital B - (Tabela 2).

Table 2 - Average of tube currents used in CT scans collected in two hospitals.

Tabela 2 - Médias das correntes de tubo utilizadas nos exames de TC recolhidos nos dois hospitais.

\begin{tabular}{|c|c|c|c|c|c|c|}
\hline & \multicolumn{3}{|c|}{ Hospital A } & \multicolumn{3}{|c|}{ Hospital B } \\
\hline & & $\begin{array}{c}\text { DLP } \\
\text { (mGy.cm) }\end{array}$ & $\begin{array}{c}\text { CTDIvol } \\
\text { (mGy) }\end{array}$ & & $\begin{array}{c}\text { DLP } \\
\text { (mGy.cm) }\end{array}$ & $\begin{array}{c}\text { CTDIvol } \\
\text { (mGy) }\end{array}$ \\
\hline \multirow{4}{*}{$\begin{array}{c}\text { Slice thickness } \\
\text { Espessura de corte }\end{array}$} & \multirow{4}{*}{0.125} & \multirow{4}{*}{$562.34 \pm 233.14$} & \multirow{4}{*}{$12.06 \pm 4.63$} & 0.3 & $732.70 \pm 243.03$ & $14.61 \pm 4.24$ \\
\hline & & & & 0.25 & 1010.5 & 19.36 \\
\hline & & & & 0.15 & $796.82 \pm 248.70$ & $15.26 \pm 4.46$ \\
\hline & & & & 0.1 & $799.83 \pm 281.37$ & $15.81 \pm 0.71$ \\
\hline \multirow{2}{*}{ Pitch } & \multirow{2}{*}{0.938} & \multirow{2}{*}{$562.34 \pm 233.14$} & \multirow{2}{*}{$12.06 \pm 4.63$} & 1.015 & $477.22 \pm 263.55$ & $9.33 \pm 4.44$ \\
\hline & & & & 1.078 & $802.97 \pm 208.39$ & $15.72 \pm 3.57$ \\
\hline
\end{tabular}


Regarding milliamperage values, the Hospital A total sample has shown an average of $192.81 \pm 66.91 \mathrm{mAs}$, with a mean of $188.88 \pm 59.65 \mathrm{mAs}$ for examinations performed with the modulated current and $201.97 \pm$ $81.80 \mathrm{mAs}$ for examinations performed with continuous current. In the Hospital B total sample, an average of $253.08 \pm 61.66 \mathrm{~mA}$, with an average of $209.85 \pm 91.38 \mathrm{mAs}$ for examinations performed with the modulated current and $261.93 \pm 49.42 \mathrm{mAs}$ in examinations with continuous current were obtained (Table 3).
Quanto aos valores de miliamperagem, no total da amostra do Hospital A temos uma média de 192,81 \pm $66,91 \mathrm{mAs}$, sendo a média de $188,88 \pm 59,65 \mathrm{mAs}$ para exames realizados com corrente modelada e de 201,97 $\pm 81,80 \mathrm{mAs}$ para exames realizados com corrente contínua. No total da amostra do Hospital B temos uma média de 253,08 $\pm 61,66$ mAs, sendo a média de 209,85 $\pm 91,38 \mathrm{mAs}$ para exames realizados com corrente modelada e de $261,93 \pm 49,42 \mathrm{mAs}$ exames realizados com corrente contínua - (Tabela 3 ).

Table 3 - Average of tube currents used in CT scans collected in the two hospitals.

Tabela 3 - Médias das correntes de tubo utilizadas nos exames de TC recolhidos nos dois hospitais.

\begin{tabular}{c|ccc}
\hline & $\begin{array}{c}\text { Tube current average of } \\
\text { examination data } \\
\text { collected (mAs) } \\
\text { Média da corrente de } \\
\text { tubo dos dados dos } \\
\text { exames recolhidos }(\mathrm{mAs})\end{array}$ & $\begin{array}{c}\text { Average tube current of the } \\
\text { examination data collected with the } \\
\text { modeled current (mAs) } \\
\text { Média da corrente de tubo dos dados } \\
\text { dos exames recolhidos com corrente } \\
\text { modelada }(\mathrm{mAs})\end{array}$ & $\begin{array}{c}\text { Tube current average of } \\
\text { examination data obtained with } \\
\text { direct current }(\mathbf{m A s}) \\
\text { Média da corrente de tubo dos } \\
\text { dados dos exames recolhidos com } \\
\text { corrente continua }(\mathrm{mAs})\end{array}$ \\
\hline Hospital A & $192.81 \pm 66.91$ & $188.88 \pm 59.65$ & $201.97 \pm 81.80$ \\
\hline Hospital B & & & $261.93 \pm 49.42$ \\
\hline
\end{tabular}

Concerning dosimetric quantities values, in Hospital A the mean DLP for the total sample was $562.34 \pm 233.14$ mGy.cm while the average values of CTDIvol was $12.06 \pm 4.63 \mathrm{mGy}$. Calculating the average value of CTDIw referenced using the above cited equation 2 , it is equal to $11.31 \mathrm{mGy}$.

In the same hospital, as mentioned above, data were collected from 70 examinations with modulated tube current and from 30 studies with continuous tube current. The mean DLP and CTDIvol of examinations performed with the modulated current was $575.01 \pm$ $223.23 \mathrm{mGy} . \mathrm{cm}$ and $12.23 \pm 4.58 \mathrm{mGy}$, respectively. In turn, tests performed with the average current value of DLP and CTDIvol were 532.79 $\pm 256.31 \mathrm{mGy} . \mathrm{cm}$ and $11.65 \pm 4.80 \mathrm{mGy}$, respectively.

In Hospital B the entire sample collected has shown a mean DLP of $767.14 \pm 236.87 \mathrm{mGy} . \mathrm{cm}$. Average values of CTDIvol was $15.02 \pm 4.16 \mathrm{mGy}$.

In Hospital B, data was collected from 17 examinations performed with modulated tube current and from 83 examinations with continuous tube current. The mean DLP and CTDIvol of examinations performed with the
Quanto aos valores das unidades dosimétricas, no Hospital A, a média dos valores de DLP no total da amostra foi de $562,34 \pm 233,14 \mathrm{mGy}$.cm enquanto que a média dos valores de CTDI ${ }_{\text {vol }}$ foi de 12,06 \pm 4,63 mGy. Calculando o valor médio de $\mathrm{CTDI}_{\mathrm{w}}$ através da equação 2 referenciada acima, corresponde a 11,31 mGy.

No mesmo hospital, como já referimos acima, foram recolhidos 70 dados de exames realizados com corrente do tubo modelada e 30 dados de exames com corrente do tubo contínua. A média de DLP e CTDI $_{\mathrm{vol}}$ dos exames realizados com corrente modelada foi de 575,01 \pm 223,23 mGy.cm e 12,23 \pm 4,58 mGy, respectivamente. Por sua vez, nos exames realizados com corrente contínua a média dos valores do DLP e CTDI $_{\text {vol }}$ foram de 532,79 $\pm 256,31$ mGy.cm e 11,65 \pm 4,80 mGy, respectivamente.

No total da amostra recolhida no Hospital B, a média dos valores DLP foi de 767, $14 \pm 236,87 \mathrm{mGy} . \mathrm{cm}$. A média dos valores de CTDIvol foi de 15,02 $\pm 4,16 \mathrm{mGy}$. No Hospital B, foram recolhidos 17 dados de exames realizados com corrente do tubo modelada e 83 dados de exames realizados com corrente do tubo contínua. A 
modulated current was $425.88 \pm 92.64$ and $9.38 \pm 2.89$ mGy, respectively. In turn, regarding tests performed with continuous current, the average of DLP and CTDIvol values were $837.04 \pm 192.30 \mathrm{mGy} . \mathrm{cm}$ and $16.18 \pm 3.37 \mathrm{mGy}$, respectively.

Through the program "CT Dosimetry" the average values CTDIvol and DLP in Hospital A were 5.01 \pm $1.74 \mathrm{mGy}$ and $218.07 \pm 91.20 \mathrm{mGy} . \mathrm{cm}$, respectively. The same quantities calculated for the Hospital B were $14,03 \pm 3.33 \mathrm{mGy}$ and $608.81 \pm 166.63 \mathrm{mGy} . \mathrm{cm}$.

Finally, the mean effective dose obtained through the CT Dosimetry software was $3.56 \pm 1.63 \mathrm{mSv}$ for Hospital A and $10.38 \pm 2.85 \mathrm{mSv}$ for Hospital B. When calculating the BERT magnitude we have obtained 1.48 years of natural radiation in Hospital A and 4.33 years of natural radiation in Hospital B.

\section{Discussion}

The undertaking of this study has allowed us to identify some limitations which could influence final results. Starting with data collection, the number of tests collected for the two types of current is clearly unbalanced. Data regarding patients' height and weight should also have been collected, since these factors significantly affect dosimetric units. However, the present sample was defined by convenience, and we have not found any evidence suggesting that the two hospitals may have significant differences with respect to the weight and height of their populations. These aspects are justified by limitations inherent to each hospital service, preventing an ideal data collection.

An important limitation regarding the data collecting equipment resulted in the absence of the mAs mean value being provided in the modulated current examinations. It was considered impractical to collect the mAs value in each slice (in some examinations, the number of slices exceeded one thousand) and the opportunity arose to download the examinations for subsequent analysis. Therefore results had to be obtained taking into account the average between the minimum and maximum $m$ As for each exam.

After analysis and comparison of collected data from the two hospitals, statistically significant differences were found between DLP $(p=0.000)$ and CTDIvol $(p=$ 0.000 ) values, revealing that dosimetric unit values are always higher in Hospital B. Probably this results from using significantly higher milliamperage.

In Hospital A there were no significant differences in the DLP values $(p=0.409)$ and CTDIvol $(p=0.566)$ for the two current types, while on the contrary, significant differences in the DLP values $(\mathrm{p}=0.000)$ and CTDIvol ( $p=0.000)$ were found in hospital $B$, where examinations performed with continuous current have média de DLP e CTDI ${ }_{\mathrm{vol}}$ dos exames realizados com corrente modelada de 425,88 \pm 92,64 mGy.cm e 9,38 \pm $2,89 \mathrm{mGy}$, respectivamente. Por sua vez, nos exames realizados com corrente contínua a média dos valores do DLP e CTDI ${ }_{\text {vol }}$ foram de 837,04 $\pm 192,30$ mGy.cm e $16,18 \pm 3,37 \mathrm{mGy}$, respectivamente.

Através do programa "CT Dosimetry" a média dos valores de CTDIvol e DLP no Hospital A foi de 5,01 \pm 1,74 mGy e 218,07 \pm 91,20 mGy.cm, respectivamente. As mesmas grandezas calculadas para o Hospital B foram de $14,03 \pm 3,33$ mGy e 608,81 $\pm 166,63$ mGy.cm.

Por fim, a média dos valores de dose efectiva obtida através do programa "CT Dosimetry" foi de 3,56 $\pm 1,63$ $\mathrm{mSv}$ para o Hospital A e de $10,38 \pm 2,85 \mathrm{mSv}$ para o Hospital B. Ao calcular a grandeza do BERT, obtivemos o valor de 1,48 anos de radiação natural no Hospital A e 4,33 anos de radiação natural no Hospital B.

\section{Discussão}

Durante a execução deste trabalho foram identificadas algumas limitações que podem influenciar os resultados finais. Começando pela recolha de dados não ser equilibrada no que diz respeito ao número de exames recolhidos com os dois tipos de corrente. Também deveriam ter sido recolhidos dados sobre o peso e altura do paciente, uma vez que estes factores afectam as unidades dosimétricas de uma forma significativa, mas uma vez que a amostra foi de conveniência, não identificámos nenhuma evidencia que sugira a existência de diferenças significativas no que diz respeito aos parâmetros do peso e altura entre os dois hospitais. Estes aspectos justificam-se pelas limitações inerentes a cada hospital, não nos permitindo uma recolha de dados ideal.

Ao longo deste estudo, outra das limitações com que nos deparámos foi o facto do equipamento onde recolhemos os dados não nos fornecer um valor médio de mAs nos exames realizados com corrente modelada, sendo inexequível a recolha do valor de $\mathrm{mAs}$ em cada corte (em alguns exames, o número de cortes ultrapassava um milhar) e dada a possibilidade de gravar os exames para uma análise à posteriori, os resultados tiveram de ser obtidos tendo em conta a média entre o valor mínimo e o máximo de mAs de cada exame.

Após a análise e a comparação dos dados recolhidos entre os dois hospitais verificou-se a existência de diferenças estatisticamente significativas entre os valores de $\operatorname{DLP}(p=0,000)$ e $\operatorname{CTDI}_{\text {vol }}(p=0,000)$, verificando-se que os valores das unidades dosimétricas são sempre superiores no Hospital B. Isto pode justificar-se pelo facto de a miliamperagem utilizada ser significativamente maior. 
always shown higher values. We must keep in mind that these results would have been more reliable if we had used equivalent sample sizes. The mean milliamperage used in examinations performed with continuous current was also relevant (Table 3 ).

By comparing the dosimetric quantities of examinations performed with the modulated current in both hospitals significant differences in DLP ( $\mathrm{p}=$ $0.009)$ and CTDIvol $(p=0.017)$ values were found, with higher values in the Hospital A. There are different equipment suppliers, resulting in different programs in both hospitals. Furthermore, radiology technicians in Hospital A perform examinations with lower values of continuous current than the milliamperage values proposed by the suppliers. This procedure reduces the image quality, although it is still suitable for medical diagnosis.

Regarding tests performed with continuous current, significant differences in the DLP $(p=0.000)$ and CTDIvol $(\mathrm{p}=0.000)$ values were found and were higher in Hospital B. Hospital B uses higher tube currents in examinations performed with continuous current.

Since there are no DRL documented for the abdominalpelvic examinations as a whole, we decided to consider the DRL for abdomen and pelvic examinations separately and get a single value for the structure under study using the following CTDIw formula:

DRL $($ CTDIw $)=($ DRL pelvis $*$ Number of slices pelvis + DRL abdomen * Number of slices abdomen) / total number of slices, considering a representative examination from our sample.

For the DLP value we have considered the sum of the DRL values from the two anatomical regions.

Relating the CTDIw and the DLP to the DRL, we found that all tests were performed in accordance with the dose limits; the CTDIw (Hospital A) equal to 11.31 mGy and the CTDIw (Hospital B) equal to $16.09 \mathrm{mGy}$, both lower than $35 \mathrm{mGy}$ that corresponds to the DRL of the CTDIw. The DLP in Hospital A was equal to 562.34 mGy.cm, while the DLP in Hospital B was 767.14 mGy.cm, which means that both are lower than $1350 \mathrm{mGy} . \mathrm{cm}$ of the DRL of DLP.

Comparing dosimetric units collected in the CT equipment from Hospital A and those obtained by the "CT Dosimetry" we have observed the existence of statistically significant differences in DLP $(p=0.000)$ and CTDIvol $(p=0.000)$ values, since the available equipment in the program could not match the CT equipment where data was collected. The model is recent and had not yet been included in the set of equipment recognized by the software. Following the supplier's instructions, we have considered an equivalent equipment, but a different model.
No Hospital A não se verificaram diferenças estatisticamente significativas dos valores de DLP $(p=0,409)$ e $\mathrm{CTDI}_{\text {vol }}(\mathrm{p}=0,566)$ entre os dois tipos de corrente, enquanto que no Hospital $B$ já existem diferenças estatisticamente significativas dos valores de $\operatorname{DLP}(p=0,000)$ e CTDI ${ }_{\text {vol }}(p=0,000)$, verificando-se que os exames realizados com corrente contínua apresentam sempre valores superiores. Devemos ter presente que estes resultados poderiam ser mais fidedignos se a recolha de dados tivesse sido realizada com amostras de dimensões equivalentes, sendo ainda influenciados pelo facto de a média da miliamperagem utilizada nos exames realizados com corrente contínua ser maior (Tabela 3).

Ao comparar as unidades dosimétricas dos exames realizados com corrente modelada nos dois hospitais constatou-se a existência de diferenças estatisticamente significativas dos valores de DLP $(\mathrm{p}=0,009)$ e $\mathrm{CTDI}_{\mathrm{vol}}$ $(\mathrm{p}=0,017)$, verificando-se que os valores são superiores no Hospital A. Esta situação pode justificar-se por as marcas dos equipamentos serem diferentes, logo existem programações diferentes nos equipamentos dos dois hospitais e pelo facto de os Técnicos de Radiologia do Hospital A ao realizarem exames com corrente contínua utilizarem valores mais baixos de miliamperagem do que os valores padronizados pelas marcas do equipamento. Assim as imagens obtidas apresentam uma menor qualidade de imagem, mas satisfatória para o diagnóstico médico.

Em relação aos exames realizados com corrente contínua constatou-se também a existência de diferenças estatisticamente significativas dos valores de $\operatorname{DLP}(p=0,000)$ e $\mathrm{CTDI}_{\mathrm{vol}}(\mathrm{p}=0,000)$, sendo estes maiores para o Hospital B. Isto porque no Hospital B se usam correntes do tubo mais elevadas nos exames realizados com corrente contínua.

Uma vez que não estão documentados os NRD para exames abdómen-pélvicos no seu conjunto, tivemos de recorrer aos NRD de exames de abdómen e de exames pélvicos separadamente e obter um único valor para a estrutura em estudo através da seguinte fórmula para o CTDI :

$\mathrm{NRD}\left(\mathrm{CTDI}_{\mathrm{w}}\right)=\left(\right.$ NRD pélvis $* n^{o}$ cortes pélvis $+N R D$ abdómen * $n^{o}$ cortes abdómen) / $n^{o}$ total de cortes, considerando um exame representativo da nossa amostra.

Para o valor do DLP somamos os valores dos NRD das duas regiões anatómicas.

Relacionando o $\mathrm{CTDI}_{\mathrm{w}}$ e o DLP com os NRD, verificase que todos os exames realizados estão de acordo com os limites de dose, sendo o CTDI ${ }_{\mathrm{w}}$ (Hospital A) de 11,31

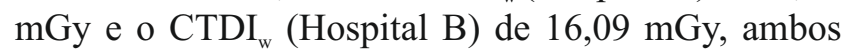
inferiores aos $35 \mathrm{mGy}^{\mathrm{de}} \mathrm{CTDI}_{\mathrm{w}}$ dos NRD. O DLP (HospitalA) de 562,34 mGy.cm e o DLP(Hospital B) 
Statistically significant differences were also found in the Hospital B for DLP ( $p=0.000)$ and CTDIvol ( $p=$ 0.000 ) values. We could not get the exact value of mAs and, for future reference, examinations must be saved in order to allow for further assessment of the value of mAs and analysis.

Regarding the effective dose calculated for both hospitals, significant differences $(p=0.000)$ were also found, with higher quantities in hospital B. This is justified for the same reason as the remaining values obtained through the "CT Dosimetry." According to the BERT parameter, we note that the exposure corresponds to a few years of natural radiation exposure, which implies a low oncological risk (Table 4). de 767,14 mGy.cm são ambos inferiores aos 1350 mGy.cm de DLP dos NRD.

Comparando as unidades dosimétricas recolhidas no equipamento de TC do Hospital A e as obtidas no programa "CT Dosimetry" verifica-se a existência de diferenças estatisticamente significativas dos valores de DLP $(p=0,000)$ e $\mathrm{CTDI}_{\text {vol }}(\mathrm{p}=0,000)$, uma vez que os equipamentos disponíveis no programa poderiam não corresponder ao equipamento de $\mathrm{TC}$ de onde foram retirados os dados, pois o modelo é recente e ainda não tinha sido incluído no conjunto de equipamentos reconhecido pelo programa, então inserimos no programa um equipamento equivalente, mas de modelo diferente.

Já no Hospital B também se registaram diferenças estatisticamente significativas dos valores de DLP $(p=0,000)$ e $\mathrm{CTDI}_{\text {vol }}(\mathrm{p}=0,000)$, as quais se podem justificar pelo facto de não termos conseguido obter o valor exacto de mAs. Por este motivo, num trabalho futuro deve salvaguardar-se a recolha dos exames para uma avaliação do valor de $\mathrm{mAs}$ à posteriori.

Em relação à dose efectiva calculada para os dois hospitais, verifica-se também a existência de diferenças estatisticamente significativas $(\mathrm{p}=0,000)$, sendo esta superior no Hospital B. Isto justifica-se pelo mesmo motivo que os restantes valores obtidos através do programa "CT Dosimetry". Segundo a grandeza BERT, podemos constatar que corresponde a poucos anos de exposição à radiação natural, o que implica um risco baixo de doença oncológica (Tabela 4).

Table 4 - Levels of additional risk of cancer resulting from exposure medical throughout life, adapted from[11] Tabela 4 - Níveis de risco adicional de cancro resultante da exposição médica ao longo de toda a vida, adaptado de [11]

Bert

A few days

Alguns dias
Additional Risk of Cancer

Risco Adicional de Cancro

\begin{tabular}{cc}
\hline $\begin{array}{c}\text { A few days } \\
\text { Alguns dias }\end{array}$ & $\begin{array}{c}\text { Negligible risk - Less than } 1 \text { case in } 1 \text { million people } \\
\text { Risco desprezável - Inferior a } 1 \text { caso em 1.000.000 pessoas }\end{array}$ \\
\hline $\begin{array}{c}\text { A few weeks a few months } \\
\text { Algumas semanas a poucos meses }\end{array}$ & $\begin{array}{c}\text { Minimal risk - Between } 1 \text { in } 1,000,000 \text { and } 1 \text { in } 100,000 \text { people } \\
\text { Risco mínimo - Entre } 1 \text { em } 1.000 .000 \text { e } 1 \text { em } 100.000 \text { pessoas }\end{array}$ \\
\hline $\begin{array}{c}\text { Few months to one year } \\
\text { Alguns meses a um ano }\end{array}$ & $\begin{array}{c}\text { Very low risk - Between } 1 \text { in } 100,000 \text { people in } 10,000 \\
\text { Risco muito baixo - Entre } 1 \text { em } 100.000 \text { em } 10.000 \text { pessoas }\end{array}$ \\
\hline Poucos anos & Low risk - Between 1 and 10,000 to 1 in 1,000 people \\
Risco baixo - Entre 1 a 10.000 a 1 em 1.000 pessoas
\end{tabular}




\section{Conclusions}

This study enabled us to conclude that the NRD was not exceeded in any of the abdominal-pelvic CT examinations performed in both hospitals.

In general it appears that the dosimetric units (CTDIvol and DLP) values obtained in hospital $\mathrm{B}$ were higher than those obtained in hospital A, knowing that in hospital B most of the tests are performed with continuous tube current, resulting in higher doses than those examinations performed with the modulated tube current.

In the hospital A the situation is inversed. Lower doses are offered to patients in studies performed with continuous tube current, although in this case the differences were not statistically significant. These examinations show lower image quality, below the standards defined by the supplier, although physicians and radiology technicians consider that they maintain enough quality for diagnosis, while reducing the exposure dose to the patient.

\section{Acknowledgements}

We convey our special gratitude to Professor Nuno Matela, for his guidance and willingness during this work.

We also thank Piedade Falcão, Carla Monteiro, Paulo Pereira and Ana Luisa Vieira, for their continuous support and monitoring.

\section{Conflict of interests}

The authors declare that there are no financial and personal relationships that could be viewed as presenting a potential conflict of interests.

\section{Conclusões}

Com este estudo conclui-se que todos os exames de TC abdómen-pélvicos realizados em ambos os hospitais não ultrapassam os NRD.

De uma forma geral constata-se que os valores das unidades dosimétricas $\left(\mathrm{CTDI}_{\mathrm{vol}}\right.$ e DLP) obtidos nos exames realizados no Hospital B são superiores aos mesmos valores obtidos no Hospital A, sabendo que no Hospital B a grande maioria dos exames são realizados com corrente do tubo contínua resultando em doses superiores aos exames realizados com corrente modelada.

Já no Hospital A a situação inverte-se, originando uma menor dose para o paciente nos exames realizados com corrente contínua, apesar de neste caso as diferenças não serem estatisticamente significativas. Esta situação pode ficar a dever-se ao facto de neste hospital os exames ficarem com uma qualidade de imagem abaixo da uniformizada pelas marcas, mas os médicos e técnicos de radiologia considerarem que mantêm qualidade de diagnóstico, permitindo diminuir a dose para o paciente.

\section{Agradecimentos}

Queremos transmitir a nossa especial gratidão ao professor Nuno Matela, pela orientação e disponibilidade demonstrada durante a elaboração deste trabalho.

Agradecemos também a Piedade Falcão, Carla Monteiro, Paulo Pereira e a Ana Luísa Vieira, pelo permanente apoio e acompanhamento nesta fase do nosso percurso académico.

\section{Conflitos de Interesses}

Os autores declaram que não existem relações pessoais ou financeiras que possam ser vistas como um potencial conflito de interesses.

\section{References / Referências}

[1]. PISCO, João. (2003). Imagiologia Básica. 1ª Ed, LIDEL-Edições Técnicas, p. 31.

[2.] RODA, Ana. (2007). Níveis de Referência de Diagnóstico em Tomografia. Tese de Mestrado. Faculdade de Medicina da Universidade de Coimbra.

[3.] GAIVÃO, Francisco. (2001). Imagiologia Clínica. $1^{\mathrm{a}}$ Ed, Imprensa da Universidade de Coimbra, pp. 129, 143, 156-58.

[4.] BRÁS, Sandra. (2006). Dosimetria do paciente em radiologia. Tese de Mestrado. Universidade do Algarve-Faculdade de Ciências e Tecnologia.
[5.] MEDEIROS, João. (2009). Qualidade de imagem versus dose em Tomografia Computorizada. Tese de Mestrado. Faculdade de Ciências e Tecnologia da Universidade de Coimbra.

[6.] Comunidade Europeia de Energia Atómica. (1997). Council Directive 97/43/EURATOM de 30 de Junho. EURATOM.

[7.] PORTUGAL. (2002). Decreto-Lei 180/2002 de 8 de Agosto. Diário da República - I Série-A.

[8.] Medical Council. (2004). The Medical Council Regulates the Medical Profession in Ireland. Medical Council of Ireland.
[9.] Matela, N.; Apontamentos de Protecção e Segurança Radiológica, do $2^{\circ}$ ano $2^{\circ}$ semestre da Licenciatura em Radiologia da Escola Superior de Saúde Ribeiro Sanches; Não publicado; 2008/2009; [10.]Kalra, M. K.; Maher, M. M.; Toth, T.L. (2004) Techniques and Applications of Automatic Tube Current Modulation for CT. Radiology, 233 (3), 649-657.

[11.] Background radiation equivalent time (BERT). In http://en.wikipedia.org/wiki/Background_radiation_eq uivalent time, acedido em 25/06/2011.

[12.]CT Dosimetry. In http://www.impactscan.org, acedido em 26/05/2011. 